\title{
KATALOG PRALATÓW I KANONIKÓW METROPOLITALNYCH ORAZ ANIWERSARZ ARCHIKATEDRY GNIEŹNIEŃSKIEJ Z ROKU 1568/1569
}

W zbiorach Archiwum Archidiecezjalnego w Gnieźnie, pod sygnaturą ACap B 77, przechowywany jest obszerny rękopis z drugiej połowy XVI w., skatalogowany później jako Cathalogus ordinatorum per Stanislaum Falencki (1563-1581) et Joannem Gniazdowski (1583-1603). Jest to zatem księga czynności pontyfikalnych dwóch kolejnych sufraganów gnieźnieńskich, sprawujących swą posługe w okresie zasiadania na stolicy prymasowskiej Jakuba Uchańskiego (1562-1581) oraz Stanisława Karnkowskiego (1581-1603), stanowiąc zarazem najstarszy tego rodzaju zabytek $\mathrm{w}$ zasobie rzeczonego archiwum ${ }^{1}$. Z obszaru historycznych ziem polskich nie są zresztą znane starsze Libri ordinatorum, aniżeli właśnie z XVI stulecia, przy czym za najwcześniejszą uważana jest księga sufragana płockiego Piotra Lubarta (Aurifabera) za lata 1515-1530, przechowywana aktualnie w zbiorach Ossolineum we Wrocławiu². Wskazany rękopis z Gniezna zainteresuje nas

${ }^{1}$ Archiwum Archidiecezjalne w Gnieźnie, oprac. M. Aleksandrowicz, J. Rył, W. Zientarski, w: Dzieje Poznania i województwa poznańskiego (w granicach z 1974 r.). Informator o materiałach archiwalnych, t. 2, red. C. Skopowski, Warszawa 1982, s. 102-103; Archiwa Kościoła katolickiego w Polsce. Informator, oprac. M. Dębowska, Kielce 2002, s. 38-39.

${ }^{2}$ Zakład Narodowy im. Ossolińskich we Wrocławiu, rkp 4874/I, Metrica ordinacionis presbyterorum et clericorum per Reverendissimum Patrem Dominum Petrum, Dei gratia episcopum Lacedemoniensem, archidiaconum, suffraganeum et canonicum Plocensem, ab Anno Domini 1515 usque ad MDXXX [zob. również: tamże, rkp 5852/III (XIX-wieczny odpis zabytku ze wstępem i indeksem opracowanymi przez W. Kętrzyńskiego)]. O źródle tym pisali: A. Tomczak, Kancelaria biskupów włoctawskich w okresie księgi wpisów (XV-XVIII w.), Toruń 1964, s. 206 przyp. 359; E. Wiśniowski, Liczebność święceń kapłańskich w diecezji płockiej w latach 1514-1530, w: Religie - edukacja-kultura, red. M. Surdacki, Lublin 2002, s. 35-46. Z kolei odnośnie do postaci biskupa Piotra Lubarta, skądinąd wybitnego humanisty i bibliofila, zarazem profesora Uniwersytetu Krakowskiego i proboszcza kościoła św. Anny w Krakowie, zob. ostatnio: K. R. Prokop, Biskupi pomocniczy w diecezjach polskich $w$ dobie przedtrydenckiej (2. pot. XIII - 1. pot. XVI w.), Kraków 2002, s. 291-293 (gdzie wskazana wcześniejsza literatura); Encyklopedia katolicka, t. 11, Lublin 2006, kol. 11 (W. Graczyk); J. Sondel, Zawsze wierny. Uniwersytet Jagielloński a Kościół rzymskokatolicki, Kraków 
wszakże nie ze względu na zawarte w nim wykazy duchownych, wyświęconych przez obu XVI-wiecznych sufraganów, bowiem z jednej strony pomieszczony tam materiał faktograficzny został już opracowany z myślą o wydaniu go drukiem przez Zdzisława Pietrzyka ${ }^{3}$, drugiej zaś istnieje kilka artykułów i przyczynków, w których mowa jest właśnie o tychże katalogach (zestawieniach) ${ }^{4}$, lecz z uwagi na pomieszczone w dalszej części kodeksu varia. Również zresztą i one zwróciły na siebie uwagę sięgających wcześniej po ten zabytek badaczy, przy czym jedna z pozycji w obrębie owych variów doczekała się nawet wydania.

Właśnie na łamach lubelskiego półrocznika „Archiwa, Biblioteki i Muzea Kościelne”, w tomie 11 z roku 1965, ukazała się mianowicie niewielka edycja źródłowa zatytułowana Nieznany katalog arcybiskupów gnieźnieńskich, przygotowana przez związanego z Prymasowskim Wyższym Seminarium Duchownym w Gnieźnie ks. Bogdana Bolza, filologa klasycznego i wybitnego znawcę średniowiecznych rękopisów liturgicznych, prowadzącego badania z zakresu kodykologii i epigrafiki ${ }^{5}$. Przedmiotem owej publikacji stał się XVI-wieczny spis arcypasterzy Kościoła gnieźnieńskiego, zawarty właśnie w rzeczonym rękopisie o sygnaturze ACap B 77 i w warstwie chronologicznej doprowadzony pierwotnie do osoby Mikołaja Dzierzgowskiego (prymas w latach 1546-1559) ${ }^{6}$. W stosownym wprowadzeniu, poprzedzającym sam tekst źródłowy, B. Bolz zamieścił też opis zabytku, z którego zaczerpnięty został zaprezentowany przezeń materiał, przy

2006, s. 154. Ponadto: S. Wielgus, Średniowieczna łacińskojęzyczna biblistyka polska, Lublin 1992, s. 135.

${ }^{3}$ Ma to być edycja pokrewna co do sposobu zaprezentowania materiału względem Ksiag egzaminów do święceń $w$ diecezji krakowskiej z lat 1573-1614, w opracowaniu tegoż samego badacza, gdzie nie mamy do czynienia z sensu stricto wydaniem źródła, lecz z podaniem zawartej w nim faktografii w formie już usystematyzowanej, w postaci swego rodzaju regestów, w których wyzyskano oryginalne brzmienie zapisek. Księgi egzaminów do święceń $w$ diecezji krakowskiej z lat 1573-1614, oprac. Z. Pietrzyk, Kraków 1991.

${ }^{4}$ Np. Z. Pietrzyk, Duchowni z powiatów opoczyńskiego, radomskiego i stężyckiego w gnieźnieńskiej księdze święceń z lat 1563-1604, w: Kościót katolicki na pograniczu małopolsko-mazowieckim w epoce przedrozbiorowej, red. S. Piątkowski, Z. Pietrzyk, Radom 2002, s. 61-73 (gdzie o samym źródle - wszakże bardzo ogólnie - w przypisie 1 na s. 61); K. R. Prokop, Wypisy źródtowe do biografii polskich biskupów i opatów z czasów Rzeczypospolitej Obojga Narodów oraz niewoli narodowej doby zaborów, „Archiwa, Biblioteki i Muzea Kościelne”, 83 (2005) s. 289, 318-319. Odnośnie do analogicznych zabytków źródłowych i świadectw z innych diecezji przedrozbiorowej Polski zob. m.in. W. Kujawski, Wykazy święconych z najstarszej księgi akt działalności biskupów włoctawskich (Kurozwęckiego i Przerębskiego - lata 1496-1511), „Archiwa, Biblioteki i Muzea Kościelne", 72 (1999) s. 23-112; A. Gąsiorowski, Święcenia $w$ diecezji kujawskiej na przełomie XV i XVI wieku, „Roczniki Historyczne”, 67 (2001) s. 79-105; T. Nowicki, Biskupi udzielajacy święceń księżom pracujacym $w$ parafiach archidiakonatu pomorskiego $w$ latach 1700-1781, w: Religie edukacja-kultura, s. 109-113.

${ }^{5}$ Zob. M. Aleksandrowicz, J. Mandziuk, Bolz Bogdan (1913-1993), kanonik kapituty gnieźnieńskiej, edytor źródet, filolog klasyczny, w: Stownik polskich teologów katolickich, t. 8, red. J. Mandziuk, Warszawa 1995, s. 108-110.

${ }^{6}$ Nieznany katalog arcybiskupów gnieźnieńskich, wyd. B. Bolz, „Archiwa, Biblioteki i Muzea Kościelne", 11 (1965) s. 271-285. 
czym poczynione przez owego badacza uwagi w tym przedmiocie $\mathrm{z}$ oczywistych względów dotyczą całego kodeksu, a nie tylko wyłącznie owego fragmentu zabytku, gdzie mieści się objęty edycją katalog. W związku z powyższym nie zachodzi potrzeba przeprowadzania w ramach obecnego przyczynku źródłowego ponownej analizy kodykologicznej interesującego nas rękopisu, tym niemniej zasadnym wydaje się podzielić się z czytelnikiem - łącząc przy tym rezultaty badań przeprowadzonych niegdyś przez $\mathrm{B}$. Bolza z obserwacjami poczynionymi z autopsji przez piszącego obecne słowa - pewnym zasobem podstawowych informacji na temat zawartości rzeczonego kodeksu oraz autorstwa i czasu powstania tych konkretnych świadectw, których dotyczy niniejsza publikacja.

Jak już na wstępie zaznaczono, omawiany rękopis ACap B 77 zawiera w swej zasadniczej części spisy czynności pontyfikalnych dwóch XVI-wiecznych sufraganów gnieźnieńskich, biskupów Stanisława Falęckiego (k. 1r-101r oraz 331r$332 \mathrm{v}$ ), wywodzącego się spośród kleru regularnego i będącego zarazem opatem klasztoru cystersów w Sulejowie, oraz Jana Gniazdowskiego (k. 105r-172r) - tak samo opata, tyle że benedyktynów w Mogilnie ${ }^{7}$. Począwszy natomiast od k. 218v, a na karcie 341r kończąc (wszakże z licznymi „po drodze” niezapisanymi kartami), znajduje się tam przebogaty zbiór variów, pośród których natrafiamy na dużo interesującego materiału dotyczącego czasów dwóch pierwszych bezkrólewi w Rzeczypospolitej Obojga Narodów. W swoim opisie rzeczonego zabytku B. Bolz stwierdza, że są to „różne wzory pism oraz kopie listów królewskich od Henryka, króla Galii i Polski (1574), różne, bez chronologii umieszczone odpisy przywilejów, np. opatów sulejowskich; potem, po pismach datowanych z lat 1574, 1576 i 1572, następują:

1) Cathalogus praelatorum et canonicorum ecclesiae metropolitanae Gnesnensis;

2) Anniversarii in ecclesia metropolitana Gnesnensi per dominos praelatos et canonicos decantandi;

3) Cathalogus sive inscriptiones archiepiscoporum ecclesiae metropolitanae Gnesnensis".

Owe trzy, następujące kolejno po sobie pozycje, spisane zostały jedną i tą samą ręka, pismem wzorowanym na kursywie humanistycznej. Mieszczący się na k. 313r-316r Cathalogus praelatorum et canonicorum ecclesiae metropolitanae Gnesnensis, rozpoczynający się zaś - zgodnie z ówczesnym stanem wiedzy (czy też raczej wyobrażeniem) o pierwocinach organizacji diecezjalnej na ziemiach polskich - od r. 966 (a więc - w ślad za Janem Długoszem - od fikcyjnych arcy-

${ }^{7}$ M.in. Z. Polkowski, Katedra gnieźnieńska, Gniezno 1874 [reprint 2005], s. 169-170, 175-176; J. Korytkowski, Prałaci i kanonicy katedry metropolitalnej gnieźnieńskiej od roku 1000 aż do dni naszych, t. 2, Gniezno 1883, s. 12-24, 76-83; C. Łuczak, Dzieje Mogilna, Poznań 1998, s. 22-23, 29; P. Hudyma, Herbarz katedry gnieźnieńskiej, Gniezno 2004, s. 75-76, 170-171; J. Augustyniak, Cysterskie opactwo w Sulejowie, Łódź 2005, s. 136, 269-271.

${ }^{8}$ Nieznany katalog arcybiskupów gnieźnieńskich, s. 271-272. 
biskupów Gniezna z X w.) $)^{9}$, doprowadzony został - o czym także wspomniano do prymasa Mikołaja Dzierzgowskiego, uwzględnionego tu już jako osoba zmarła, z podaniem daty śmierci, przy czym nieco wcześniej pozostawiono puste miejsce na opuszczony „biogram” prymasa Piotra Gamrata (w XVII w. inna ręka dopisała imiona kolejnych metropolitów od Jana Przerębskiego do Macieja Łubieńskiego). W swym wprowadzeniu do wyżej przywołanej edycji źródłowej, w paragrafie Czas powstania katalogu gnieźnieńskiego B 77 i Autorstwo katalogu, B. Bolz skoncentrował się w sposób wyraźny w swych dywagacjach właśnie na owej drugiej kwestii, dochodząc do przekonywująco uzasadnionego wniosku, że autorem interesujących nas wpisów był Jan Pakoszewski, kleryk diecezji krakowskiej i notariusz publiczny (notarius publicus), zarazem też dworzanin i notariusz arcybiskupa Jakuba Uchańskiego ${ }^{10}$. Co się tyczy natomiast pierwszego z zasygnalizowanych zagadnień, to - oszczędziwszy czytelnikowi jakichś obszerniejszych wywodów w tej materii - wydawca źródła ograniczył się do konkluzji, iż „wystarczające prawdopodobieństwo przemawia za tym, że Katalog powstał w okresie między wrześniem 1568 a r. 1569”, dodając w nawiasie: „por[ównaj] spis prałatów i kanoników" "11. A zatem uzasadnienie przyjętej przez B. Bolza datacji zabytku wynikać ma z owego materiału, który przezeń edycją objęty nie został, stąd zainteresowanej osobie nie pozostawało nic innego, jak albo uwierzyć wydawcy na słowo, albo też we własnym zakresie przystąpić do przestudiowania zawartości gnieźnieńskiego rękopisu o sygnaturze ACap B 77. Obecna publikacja sytuację w owym względzie zmienia, jako że z jednej strony ogół zainteresowanych otrzymuje do ręki w postaci drukowanej pominięte przez B. Bolza rzeczone dwa spośród trzech konstytuujących pewną całość XVI-wiecznych zestawień czy też wykazów (katalog prałatów i kanoników metropolitalnych, aniwersarz archikatedry gnieźnieńskiej, katalog arcybiskupów Gniezna), z drugiej zaś obowiązkiem piszącego te słowa jest choćby pokrótce omówić kwestię datacji zabytku, co też poniżej czynimy.

Punkt wyjścia dla naszych dywagacji stanowi umotywowany w sposób dostateczny przez ks. Bolza wniosek, iż wszystkie trzy wyżej wspomniane spisy nie tylko wyszły spod jednej ręki, ale też sporządzone zostały w jednym czasie. Tym samym w miare precyzyjne ustalenie momentu powstania któregokolwiek spośród nich pozwala na wydatowanie całości, jak zaś słusznie wskazał przywołany tu kilkakrotnie badacz, najdogodniejszą podstawę dla poczynienia w tym względzie wiążących konstatacji daje właśnie Cathalogus praelatorum et canonicorum ecclesiae metropolitanae Gnesnensis. Zgodnie z przyjętym zwyczajem, członkowie gnieźnieńskiej kapituły archikatedralnej zostali wymienieni tamże w dwóch grupach, mianowicie wpierw prałaci, a następnie kanonicy, W pierwszej z owych grup o kolejności, w jakiej dokonano wyliczenia, decydowało „starszeństwo”

${ }^{9} \mathrm{~W}$ przedmiocie genezy owej błędnej chronologii pasterzy Kościoła gnieźnieńskiego w odniesieniu do czasów pierwszych Piastów autor obecnego przyczynku pisał ostatnio w obszernym studium Blogosławiony arcybiskup Radzim-Gaudenty $i$ zagadnienie poczatków metropolii gnieźnieńskiej w historiografii staropolskiej (w druku).

${ }^{10}$ Nieznany katalog arcybiskupów gnieźnieńskich, s. 276-279 (zwłaszcza s. 278-279).

${ }^{11}$ Tamże, s. 277. 
godności zajmowanej w kapitule, ta zaś była następująca: prepozyt, dziekan, archidiakon, kantor, scholastyk, kustosz i kanclerz ${ }^{12}$. Co się tyczy natomiast „zwyczajnych" kanoników, o precedencji decydowała w ich przypadku z kolei długość przynależenia do kapituły, czyli czas upływający od momentu przyjęcia do jej grona. Taki też porządek znajdujemy w Acta actorum capituli metropolitanae Gnesnensis, w wykazach obecności członków tego nobliwego grona na poszczególnych sesjach partykularnych i w szczególności generalnych. W jednym tylko względzie interesujący nas obecnie spis różni się w stosunku do owych wykazów $\mathrm{z}$ akt kapitulnych, mianowicie umieszczeniem w nim na samym początku - niewątpliwie dla wyrażenia uszanowania względem godności biskupiej - sufragana gnieźnieńskiego Stanisława Falęckiego. Zresztą mamy tu przecież do czynienia z jego własną księgą czynności pontyfikalnych, więc notariuszowi (pisarzowi) zgoła nie wypadało nie okazać mocodawcy rewerencji poprzez tego rodzaju wyróżnienie, choć z drugiej strony poczuwał się on zobligowanym, by zaznaczyć też, jakie w rzeczywistości miejsce, gdy chodzi o precedencję, biskup Falęcki zajmuje w gnieźnieńskiej kapitule. Stąd też w części odnoszącej się do „Zwyczajnych" kanoników po raz wtóry wymieniony został - dopiero na pozycji dwunastej - Stanislaus Phalenczki, z dodaniem: canonicus Gnesnensis (skądinąd zaś wiemy, że nie było w tym czasie w owym gremium kapitulnym innego Stanisława Falęckiego, więc nie może chodzić o dwie różne osoby o tym samym imieniu i nazwisku).

Wydaje się rzeczą oczywista, że zawarte w rękopisie o sygnaturze ACap B 77 wyliczenie członków gnieźnieńskiej kapituły metropolitalnej odzwierciedla jej skład w jakimś określonym momencie dziejowym, więc w kontekście określenia chronologii zabytku naszym zadaniem jest stwierdzić, kiedy konkretnie tak właśnie prezentowało się owo grono kapitulne, gdy chodzi o aspekt personalny. Jeśli pominać osobę wymienionego na samym początku Stanisława Falęckiego, który obowiązki sufragana sprawował w latach 1562-1581, zaś do kapituły należał począwszy od rzeczonego roku 1562 , to - spoglądając na daty piastowania wskazanych w owym spisie godności kapitulnych przez wymienionych tam siedmiu prałatów - uzyskujemy przedział czasu pomiędzy wrześniem 1568 r. a sierpniem 1573 r. $^{13}$ Jeśli przyjrzeć się natomiast pod tym kątem gronu 22 kanoników (z bi-

${ }^{12}$ Por. J. Korytkowski, Prałaci i kanonicy, t. 1, cz. 1, Gniezno 1883, s. $21 \mathrm{nn}$.

${ }^{13}$ Terminus a quo wyznacza w tym przypadku instalacja 12 IX 1568 na prepozyturę Łukasza Podoskiego, przy czym należy w tym miejscu odnotować, że tak samo w roku 1568 kantorię objął Stanisław Ossowski (instalowany 6 IV tr.), zaś scholasterię Stanisław Krasiński (brak informacji o dokładnej dacie). Jeśli chodzi z kolei o terminus ad quem, to wyznacza go zgon w dniu 2 VIII (nie 2 II!) 1573 dziekana Jana Korzboka Witkowskiego, także zresztą w aniwersarzu wspomnianego jako osoba jeszcze żyjąca. - Archiwum Archidiecezjalne w Gnieźnie, sygn. ACap B 20 - Liber actorum Venerabilis Capituli Ecclesiae Metropolitanae Gnesnensis, vol. VII (1555-1570), passim; tamże, sygn. ACap B 21 - Acta Venerabilis Capituli Gnesnensis, vol. VIII (1570-1587), passim; J. Korytkowski, Prałaci i kanonicy, t. 2, s. 352; t. 3, Gniezno 1883, s. 175, 241; t. 4, Gniezno 1883, s. 314315. Także B. Paprocki, Herby rycerstwa polskiego, wyd. K. J. Turowski, Kraków 1858 [reprint: Warszawa 1988], s. 723; W. Urban, Korzbok Witkowski (Korzboch, Korczboch, Koczbork, Cordsbogk, Corcibok, Korzbog, Kurzbach z Witkowa) Jan herbu własnego (koniec XV w. - 1572), pratat, 
skupem S. Falęckim - 23), wskazany wyżej przedział czasu władni jesteśmy zawęzić, przesuwając terminus ad quem na październik 1569 r. ${ }^{14}$

Być może odwołanie się do szerszej podstawy źródłowej pozwoliło by jeszcze precyzyjniej uchwycić ramy chronologiczne, w których skład gnieźnieńskiej kapituły metropolitalnej przedstawiał się tak właśnie, jak to zostało ukazane w omawianym zestawieniu, choć z drugiej strony trzeba mieć świadomość, że owo dążenie do większej precyzji w tym względzie wcale nie musi doprowadzić do pożądanego rezultatu. Ustalenie precedencji kanoników wedle „starszeństwa” przynależności natrafia bowiem nieraz na poważne przeszkody związane z toczonymi przez samych zainteresowanych sporami w owej materii. Należy pamiętać, że proces „wchodzenia” do kapituły był rozciagnięty w czasie (prowizja, recepcja, instalacja, uroczyste złożenie przysięgi), a obok tego nie należały bynajmniej do rzadkości długotrwałe spory o konkretną prałaturę czy kanonikat pomiędzy

mecenas kultury, w: Polski Stownik Biograficzny [dalej: PSB], t. 14, Wrocław 1968-1969, s. 160; tenże, Krasiński Stanisław herbu Ślepowron (1534-1598), sekretarz królewski, prałat kilku kapitut, PSB, t. 15, Wrocław 1970, s. 190-191; H. E. Wyczawski, Ossowski Stanisław herbu Gryf (zm. 1580), prałat włocławski, referendarz koronny, PSB, t. 24, Wrocław 1979, s. 444-445; R. Żeleński, Podoski Łukasz herbu Junosza (1526-1584), kanonik krakowski, prepozyt gnieźnieński, sekretarz królewski i dyplomata, PSB, t. 27, Wrocław 1983, s. 171-173; Corpus inscriptionum Poloniae, t. 8: Województwo krakowskie, z. 1: Katedra krakowska na Wawelu, wyd. A. Perzanowska, red. R. M. Zawadzki, Kraków 2002, s. 443-444 nr 71.

${ }^{14} \mathrm{~W}$ tej z kolei, o wiele liczniejszej grupie, gdy chodzi o terminus a quo, punkt odniesienia stanowią dla nas instalacje ostatnich spośród wyliczonych w Katalogu kanoników, a więc Sebastiana Magnuszewskiego (27 XII 1567), Jana Rembielińskiego (26 III 1568), Józefa Zamoyskiego (6 V 1568) oraz Jana Łoskiego (16 VI 1568), przy czym należy odnotować, że w interesującym nas zestawieniu nie widnieje imię opata mogileńskiego Jana Gniazdowskiego (późniejszego sufragana gnieźnieńskiego), którego recepcja, jako kanonika „urodzonego” (canonicus natus), miała miejsce 14 VI 1568. Nieco więcej wątpliwości może nastręczać terminus ante quem, o ile bowiem według zestawienia sporządzonego przez J. Korytkowskiego kolejnym kanonikiem gnieźnieńskim, instalowanym po Janie Łoskim, miał być Szymon Borszyński (dopiero 20 XII 1570), o tyle przy okazji sesji generalnej 20 X 1569 wymienieni zostali w Acta actorum dwaj inni jeszcze członkowie rzeczonego gremium, mianowicie Wawrzyniec Modliszewski oraz Jan Piotrowski - ów pierwszy przed, drugi zaś po J. Zamoyskim (J. Łoski był natomiast nieobecny, stąd w odnośnym wyliczeniu go pominięto). Tyle, że w rzeczywistości obaj oni instalowani zostali o wiele wcześniej, mianowicie W. Modliszewski 16 III 1564, natomiast J. Piotrowski 26 IX 1566, stąd chodzi tu o duchownych wówczas już od kilku lat należących do owego nobliwego gremium. Rzeczony W. Modliszewski otrzymał też w dzień później (21 X 1569) kurię kanoniczą, zwolnioną w związku ze śmiercią Jakuba Grylewskiego (przypomnijmy, iż w interesującym nas zestawieniu uwzględniony jest jako osoba żyjąca), przy czym także w związku z sesją generalną w dniu 30 III 1570 został on wymieniony przez Józefem Zamoyskim, po którym i tym razem następuje w wyliczeniu wspomniany tu już Jan Piotrowski. Ówże rok 1570 przyniósł też rezygnację z kanonikatu w kapitule metropolitalnej gnieźnieńskiej Stanisława Iłowskiego (dokładna data nieznana). - Archiwum Archidiecezjalne w Gnieźnie, sygn. ACap B 20, passim (zwł. k. 317r, 330r-v, 337v-338v [Electio et receptio Domini Zamoyski], 339v [Receptio Domini Abbatis Mogilnensis], 344r-v, 360v, 361r [Habilitatio Domini Ioannis Piotrowski], 370v-371r [Provisio domus Domino Modliszewski]); tamże, sygn. ACap B 21, passim (zwł. k. 1r oraz 2r-v, gdzie usprawiedliwienie nieobecnych na sesji kanoników); J. Korytkowski, Prałaci $i$ kanonicy, t. 2, s. 166, 531-532, 583; t. 3, s. 33, 221, 245, 358; t. 4, s. 555-556. 
dwoma lub też większą liczbą rywalizujących duchownych, z których każdy powoływał się na jakieś bardziej lub mniej uzasadnione tytuły prawne. Prowadziło to czasem do przewlekłych procesów przed trybunałami kościelnymi, skutkiem czego bywało, że włączony ostatecznie do grona kapitulnego kandydat, który zdołał pokonać rywali, w porządku precedencji mógł uzyskać wyższe miejsce, aniżeli kanonicy przyjęci do gremium kapitulnego w trakcie trwania danego procesu. Zresztą w aktach kapituł katedralnych i kolegiackich z doby staropolskiej niemało jest wpisów dotyczących powtórnej czy nawet którejś z kolei z rzędu recepcji kanonika, co siłą rzeczy prowadziło do większego jeszcze zamieszania w materii „starszeństwa”. Tego pochodną stanowią zauważalne w wykazach obecności kanoników na sesjach generalnych i partykularnych zmiany w kolejności ich wyliczenia, stąd wspomniane dążenie do bezwzględnej precyzji w wydatowaniu interesującego nas spisu może okazać się ułudne. Wypada nam zatem uznać za zadowalający ów roczny przedział czasu, na jaki wyżej wskazano, łącząc tym samym powstanie rzeczonego świadectwa z rokiem 1568 lub 1569 (a zatem w zgodzie z ustaleniami B. Bolza), przy czym - jak już zaznaczono w przypisie 14 - pewien dysonans w kontekście rzeczonej konkluzji wprowadza niewymienienie w tymże zestawieniu ówczesnych członków kapituły metropolitalnej z Gniezna kanoników Wawrzyńca Modliszewskiego (instalowany 16 III 1564) i Jana Piotrowskiego (instalowany 26 IX 1566), którzy we wskazanym przedziale czasu należeli wciąż do grona osób żyjących (zmarli dopiero w latach 1586-1588) i bynajmniej nie zrezygnowali z posiadanych kanonikatów. Ich nieobecność w owym wykazie stanowi zatem pewną zagadkę, choć z drugiej strony trudno na tej podstawie dokonać jakiejś nie nastręczającej kolejnych wątpliwości korektury zaproponowanych wyżej dat, przy których zatem pozostaniemy.

Poniższa edycja źródłowa obejmuje tedy wspomniane tu już kilkakrotnie dwa zestawienia - katalog prałatów i kanoników metropolitalnych oraz aniwersarz gnieźnieńskiej archikatedry, pomieszczone w takiej kolejności, w jakiej widnieją one w oryginale w rękopisie ACap B 77. Ów pierwszy zawarty jest mianowicie na k. 311r, gdzie nazwiska członków rzeczonego gremium kanoniczego podano w układzie dwukolumnowym, z czego wydawca - ze względów praktycznych zdecydował się zrezygnować. Zarówno w przypadku katalogu, jak i aniwersarza, zachowano oryginalną pisownię imion i nazwisk, dokonując wszędzie rozwiązania zastosowanych przez pisarza skrótów (tym bardziej, że nie wzbudzały one wattpliwości).

Co się tyczy jeszcze kwestii zasadniczych, związanych z regułami przyjętymi w edycji, to zrezygnowano całkowicie z objaśniania poszczególnych postaci poprzez umieszczanie w przypisach not biograficznych o każdej z nich. I w tym przypadku zadecydowały względy praktyczne, bowiem z jednej strony dołączenie tego rodzaju notek istotnie by przymnożyło objętości niniejszej edycji, z drugiej zaś w sytuacji, gdy dysponujemy wartościowym i opartym przeważnie na materiale archiwalnym obszernym słownikiem biograficznym kapituły metropolitalnej gnieźnieńskiej w opracowaniu ks. Jana Ignacego Korytkowskiego (nota bene 
zmarłego jako biskup-nominat) ${ }^{15}$, podana przez nas faktografia $\mathrm{w}$ zasadzie niewiele by wniosła do stanu badań, przynosząc znikomy pożytek nauce. Wprawdzie w aniwersarzu trafiają się postaci i spoza rzeczonego grona, jednakże są to niemal wyłącznie arcybiskupi Gniezna, do których wszak odnosi się jeszcze bogatsza, aniżeli w przypadku kanoników, literatura przedmiotu ${ }^{16}$.

Oczywiście nieprawdziwym byłoby z drugiej strony twierdzenie, że wspomniane wyżej dzieło J. Korytkowskiego, ogłoszone drukiem wszak przed przeszło 120 laty, po dziś dzień stanowi „ostatnie słowo” nauki. Tak bynajmniej nie jest i zwłaszcza w odniesieniu do kanoników gnieźnieńskich z późnego średniowiecza nasza wiedza wzbogaciła się ostatnimi czasy o kolejne ustalenia ${ }^{17}$. W omawianym przypadku chodzi wszakże w większości o postaci z XVI stulecia, gdy tymczasem co raz żywsze obecnie badania nad prozopografią środowisk kapitulnych w dawnej Polsce koncentrują się zasadniczo jednak na wiekach średnich, tylko $\mathrm{z}$ rzadka wkraczając $\mathrm{w}$ epokę nowożytną. W konsekwencji w odniesieniu do kapituł staropolskich pozostaje nam niezmiennie odwoływać się przy poszukiwaniach prozopograficznych do publikacji o sędziwej metryce, często jeszcze XIXwiecznych, a przede wszystkim siegać bezpośrednio do niepublikowanego materiału źródłowego. To drugie stanowi zresztą obowiązek badacza i zgoła dziwić może, że wielu poprzestaje jednak na powtarzaniu nie zawsze ostających się później przy konfrontacji ze świadectwami archiwalnymi domysłów i przypuszczeń wcześniejszych generacji czy to historyków, czy też - co częściej - pasjonatów

${ }^{15}$ J. Korytkowski, Prałaci i kanonicy katedry metropolitalnej gnieźnieńskiej od roku 1000 aż do dni naszych, t. 1-4, Gniezno 1883. Zob. także J. Jaskulski, Dzieło ks. Jana Ignacego Korytkowskiego w ocenie historiografii i metodologii XIX i XX wieku, w: 1000 lat archidiecezji gnieźnieńskiej, red. J. Strzelczyk i J. Górny, Gniezno 2000, s. 407-417.

${ }^{16}$ Przede wszystkim J. Korytkowski, Arcybiskupi gnieźnieńscy, prymasowie i metropolici polscy, od roku 1000 aż do roku 1821, czyli do połaczenia arcybiskupstwa gnieźnieńskiego z biskupstwem poznańskim, t. 1-5, Poznań 1888-1892. Z nowszych zbiorów sylwetek arcypasterzy Kościoła gnieźnieńskiego: M. Kosman, Między ottarzem a tronem. Poczet prymasów Polski, Poznań 2000; K. R. Prokop, Arcybiskupi gnieźnieńscy w tysiacleciu, Kraków 2000; K. Śmigieł, Stownik biograficzny arcybiskupów gnieźnieńskich i prymasów Polski, Poznań 2002; P. Mrozowski, Poczet arcybiskupów gnieźnieńskich - prymasów Polski, Warszawa 2003. Warto zwrócić ponadto uwagę, że również w wydawanym obecnie wykazie kanoników znajdujemy imiona kilku późniejszych biskupów (jakkolwiek akurat żaden z nich nie doszedł w swej karierze kościelnej do stolicy prymasowskiej), mianowicie - obok wspomnianego już Stanisława Falęckiego - Franciszka Krasińskiego, Piotra Dunin-Wolskiego i Jakuba Milewskiego (pierwszy miał być ordynariuszem krakowskim, drugi ordynariuszem płockim, trzeci zaś sufraganem w Krakowie).

${ }^{17}$ Przykładowo: M. D. Kowalski, Prałaci i kanonicy krakowskiej kapituły katedralnej od pontyfikatu biskupa Nankera do śmierci biskupa Zawiszy z Kurozwęk (1320-1382), Kraków 1996, s. 302-304 (Mikołaj z Łagiewnik i Ułanowa herbu Sulima, syn Strzeszka); M. Czyżak, Kapituła katedralna w Gnieźnie w świetle metryki z lat 1408-1448, Poznań 2003, s. 341-342 (Jan Furman z Mchów (z Niezamyśla) herbu Doliwa), 360-361 (Mikołaj Słupek z Budzisławia herbu Sulima), 371-372 (Mikołaj Strzeszkowic z Łagiewnik Kościelnych i z Ułanowa herbu Sulima); A. KowalskaPietrzak, Prałaci i kanonicy kapituły tęczyckiej do schyłku XV wieku, Łódź 2004, s. 82-86 (Jan Furman z Zniemyśla herbu Doliwa); A. Jabłońska, Kapituła uniejowska do poczq̨tku XVI wieku, Kielce 2005, s. 170-171 (Mikołaj Słupek z Budzisławia herbu Sulima). 
przeszłości, prowadzących swe poszukiwania nieraz bez fachowego po temu przygotowania.

W owym kontekście tym donioślejszą jawi się potrzeba wydawania drukiem źródeł, dzięki czemu poszerzeniu ulega podstawa prac badawczych prowadzonych dziś wszak w rozmaitych ośrodkach regionalnych przez osoby dla tych lub innych względów nie zawsze podejmujące własne kwerendy archiwalne. Zresztą przecież i najbardziej nawet wytrwały kwerendzista nie jest w stanie - gdy chodzi o świadectwa z czasów nowożytnych oraz późniejszych - dotrzeć do wszystkich interesujących go materiałów, rozproszonych po wielu zbiorach i kolekcjach, stąd każdą edycję źródłową powita zapewne z życzliwym zainteresowaniem. Z tą też myślą publikujemy rzeczony katalog i aniwersarz z lat 1568-1569, które wraz $\mathrm{z}$ wydanym niegdyś przez $\mathrm{B}$. Bolza spisem arcybiskupów gnieźnieńskich stanowić będą użyteczny materiał nie tylko dla historyków Kościoła w Polsce doby odrodzenia i reformacji. Wypada też zawrzeć na koniec postulat ogłoszenia drukiem w przyszłości także owych pozostałych variów z rękopisu ACap B 77 zwłaszcza zaś tych, które odnoszą się do bezkrólewi z lat 1574 i 1576, jako że ich wartość poznawcza dla badacza epoki jest trudna do przecenienia (zwłaszcza wobec czy to bezpowrotnej utraty, czy też czasowej niedostępności wielu świadectw do dziejów przedrozbiorowych ziem polskich i życia ich mieszkańców).

$* \quad * \quad *$

\title{
k. $311 r$ \\ Cathalogus Praelatorum et Canonicorum Ecclesiae Metrop[oli]t[a]na[e] Gnesn[ensis]
}

\section{Praelati}

Stanislaus Phalienczki, Dei gratia Episcopus Theodosien[sis] et Suffraganeus Gnesn[enesis]

Lucas Podoski, praepositus

Joannes Cordzbok Withkowski, decanus

Stanislaus Dambrowski I[uris] V[triusque] D[octor], archidiac[onus]

Stanislaus Ossowski, cantor

Stanislaus Krassinski, scholasticus

Clemens Rudniczki, custos

Hieronymus Garwaski, cancellarius

\section{Canonici}

\author{
Martinus Lopateczki \\ Petrus Wolski \\ Martinus Russieczki I[uris] V[triusque] Doctor \\ Nicolaus a Cracowia, Medicinae Doctor, supernumerarius \\ Jacobus Mylewski \\ Martinus Zidowski
}




\author{
Albertus Zabinski \\ Franciscus Crassinski I[uris] V[triusque] Doctor \\ Nicolaus Krassinski \\ Ioannes Zimlinski \\ Petrus Przerembski \\ Stanislaus Phalienczki, can[oni]c[us] Gnesnen[sis] \\ Stanislaus Grotkowski \\ Ioannes Cokaliewski \\ Ioannes Powodowski \\ Erasmus Mieleński \\ Christopherus Podoski \\ Stanislaus Ilowski, Sacrae Theologiae et Iuris Vtriusque Doctor \\ Jacobus Grilewski \\ Sebastianus Magnuschewski \\ Ioannes Rembielinski \\ Josephus Zamoiski I[uris] V[triusque] Doctor \\ Ioannes Łoski
}

\title{
k. $311 v$
}

\section{Anniversarii in Ecclesia Metrop[o]I[ita]na Gnesnen[si] per dominos Pra- elatos et Canonicos decantandi}

\section{Ianuarius}

II. Die Mensis Ianuarii: Nicolai Strzeskonis, archidiaconi Gnensnen[sis]

IIII. Die eiusdem mensis: R[evere]n[dissi]mi d[omi]ni Andreae Cricii, archiepiscopi Gnesnen[sis], missa in eius Sacello de quinque vulneribus D[omi]ni n[ost]ri Iesu Christi, decantan[da] cum collectis pro Episcopo et s. Andreae

$\mathrm{X}$. Eiusdem mensis: Alberti Zaluski, canonici Gnesnen[sis]

XVIII. R[evere]n[dissi]mi d[omi]ni Nicolai Dzierzgowski, archiepiscopi Gnesn[ensis]

XXII. Mensis: depositionis Ioannis Buschinski, suffraganei Gnesn[sis]

XXIIII. Eiusdem mensis: Ioannis Baruchowski, canonici

\section{Februarius}

III. Mensis eiusdem: Pauli Chodakowski, canonici

VII. Andreae Cricii missa in eius sacello ut supra

XIII. Mensis: Alberti Zaluski, canonici

XX. Dzierzgowski, in die sepulturae, vigiliae IX Lectionum

Feria secunda post septuagesimam Ioannis Brozowski, cantoris, et Petri de Kobylino, canonici

\section{Martius}

II. Ioannis Korzbog Witkowski, decani Gnesn[ensis], missa in vita eius pro peccatis, post mortem vero Nos aut [em] gloriari etc. de sancta Cruce 
$X$. Andreae Cricii missa in eius sacello

XVII. Ioannis Bussinski, suffraganei

XXII. Stanislai Kilowski

Feria sexta post Dominicam Iudica Joannis Kordzbog Witkowski, decani Gnesnen[sis], Missa de sancta Cruce. Nos aut[em] gloriari oportet etc.

\section{Aprilis}

XV. Mensis: Andreae Cricii in eius sacello

XX. R[evere]n[dissi]mi d[omi]ni Ioannis Sprowski, archiepiscopi Gnesnen[sis]

XXII. Eiusdem Mensis: Ioannis et Foelicis Naropinskich fratrum

XXIIII. Nicolai Dzierzgowski in eius sacello missa in honorem poenarum Domini nostri Iesu Christi cum Introitu Ecce vidimus Dominum nostrum Iesum, cum collectis de doloribus Beatae Virginis, ac pro Episcopo $O[\mathrm{mi}] p[$ oten $] \mathrm{s} \mathrm{sempi-}$ terne Deus qui facis mirabilia etc.

XXVI. Eiusdem Mensis: votiva Cricii in eius sacello

XXVII. R[evere]n[dissi]mi d[omi]ni Sprowski, archiepiscopi

\section{k. $312 r$.}

XXVIII. R[evere]n[dissi]mi d[omi]ni Mathiae Drevicii, archiepiscopi Gnesnen[sis]

Die Veneris ante Dominicam Conductus Paschae vigiliae IX Lectionum Domini Stanislai Kilowski

\section{Maius}

Quinta eiusdem mensis Bartholomaei Gatkowski, cancellarii Gnesn[ensis] votiva de sancta Cruce. Nos aut [em] gloriari etc. cum collecta de Beata Virgine. Interveniat pro nobis D[omi]ne Iesu Christe pro sacerdote et sancto Bartholomeo

XII. Ioannis Furman, custodis Gnesnen[sis] de domo Dria

XVI. Andreae Laski, custodis Gnesn[ensis]

XXII. Andreae Cricii, archiepiscopi, missa in sacello eius

Ultima eiusdem mensis: Clementis Bussinski, canonici

Feria sexta in crastino Ascensionis Domini, votiva Andreae Cricii in eius sacello

Die Satruni post festum Ascensionis Domini: Ioannis Cokaliewski in sacello $\mathrm{R}$ [evere]n[dissi]mi $\mathrm{D}$ [omi]ni Cricii missa de quinque vulneribus $\mathrm{D}$ [omi]ni $\mathrm{n}$ [ost]ri $\mathrm{Ih}[\mathrm{es}] \mathrm{u}$ Chri[sti], cum collectis in vita pro $\mathrm{p}[\mathrm{ec}] \mathrm{c}[\mathrm{a}] \mathrm{tis}$, post mortem pro sacerdote et de s. Ioanne Baptista

\section{Iunius}

VII. Die men[sis]: Pauli Chodakowski, missa cum collecta pro plurib[us] sacerdotibus

XIII. Andreae Cricii missa in sacello eius

XIX. Ioan[nis] Bussinski, suffraganei Gnesn[ensis]

XXIII. Slupkonis, canonici 
XXVII. Slupkonis, canonici

XXVIII. Pauli Chodakowski, canonici Gnesn[ensis]

Die Veneris in crastino octava Corporis Christi anniversarium Doctoris Simonis, theologi excellentissimi, in die depositionis missa de Sancta Trinitate cum colecta pro sacerdote

Die Veneris in crastino Corporis Christi votiva de Sancta Trinitate olim D[omi]ni Michaelis Krzizankowski, vicedecani, cum collectis de Corpore Christi, de Beata Virgine, de pluribus sacerdotibus et de sancto Michaële

\section{Julius}

4. Eiusdem mensis: Andreae Cricii missa in eius sacello

8. Die: Ioannis Grod, Doctoris, canonici Gnesn[ensis]

12. Depositionis nobilis Gregorii Lienartowski

14. Ioannis Iwanowski, canonici

19. Gregorii Lienartowski

21. Joannis Iwanowski, canonici

28. Alberti Zaluski, canonici Gnesn[ensis], missa de Assumptione Beatae Virginis cum collectis pro sacerdote

\section{Augustus}

3. Eiusdem mens[is]: Doctoris medici Andreae Grodziczki, canonici

8. Eiusdem: Doctoris Grodziczki, canonici

12. Eiusd[em] mensis: Alberi Załuski, canonici, missa de s. Adalberto

16. Stanislai Mielzinski, custodis

18. Alberti Załuski, canonici

21. Depositionis R[evere]n[dissi]mi domini Mathiae Drevicii, archiepiscopi

26. Andreae Cricii, archiepiscopi, in sacello eius missa

27. Joannis Baruchowski, canonici Gnesnensis

k. $312 v$

\section{September}

1. Die eiusdem mensis: Stanislai Kilowski, canonici

5. Andreae Cricii, missa in sacello eius

9. Joannis Ribienski, canonici

12. Andreae Carssowski, civis Gnesnen[sis]

16. Eiusdem Andreae Carssowski, civis Gnesnen[sis]

17. Pauli Chodakowski, canonici

20. Alberti Zichlinski

26. Stanislai Kilowski, canonici

\section{October}

1. Die: Joannis Rudniczki, canonici

5. R[evere]n[dissi]mi domini Jacobi Szienienski, arch[iepiscopi]

8. Stanislai Mielzinski, custodis Gnensn[ensis] 
13. $\mathrm{R}$ [evere]n[dissi]mi d[omi]ni Grusczinski, archiepi[scopi]

19. Doctoris Groth, canonici

22. Andreae Cricii, archiepi[scopi], missa in sacello eius

23. R[evere]n[dissi]mi Joannis Sprowski, archiepi[scopi]

24. R[evere]n[dissi]mi Mathiae Drevicii

25. Joannis et Foelicis Naropinskich, fr[atru]m

26. Nicolai Dzierzgowski, archiepiscopi Gnensnens[is], in eius sacello votiva de sancto Adalberto cum collectis de quinque vulneribus Domini, de Beatae Virgine, et pro Episcopo Om[ni]p[oten]s sempiterne Deus qui facis mirabilia etc.

29. Joannis et Foelice Naropinskich fr[atru]m

\section{November}

3. Andreae Cricii, archiepi[scopi], missa in sacello eius

7. Eiusdem: Joannis Rudniczki, canonici

10. Mathiae Lanczki, archidiaconi Gnensn[ensisi], depositionis, Missa de Sancta Trintate cum collectis de Beatae Virgine, pro sacerdote et de sancto Mathia Apostolo

13. Nobilis Iacobi Drogomierz, depositionis ipsius

17. Pauli Chodakowski

20. Nobilis Jacobi Drogomierz in octava depositionis

27. Nicolai Chebda, canonici

\section{December}

Prima eiusdem Andreae Cricii, archiepiscopi, missa in eius sacello

IX. Alberti Załuski, missa de Assumptionis Beatae Virginis cum collectis pro sacerdote, de s. Adalberto

14. R[evere]n[dissi]mi d[omi]ni Joannis Laski, archiepiscopi

20. Stanislai Kilowski, canonici

Vigilia fr[ater]nitatis singulis quattuor temporibus anni feria sexta peraguntur a quibus interessentibus per gross[os] quattuor solvitur et vicariis ni[hi]l da[n]tur

Vigiliae conclusionis Cap[itu]li duplices per grossos quattuor et vicariis 24 gr[ossos] dantur

[dopisane poniżej aniwersarza, na k. $312 \mathrm{v}$.

Mortuo Praelato et Canonico circa Ecclesiam omnes residentes Praelati et Canonici pariter et viccarii convenient in domum mortui et cantent vigilias IX Lectionum a quibus ni[hi]l datur. Tandem in die depositionis cantabunt in Ecclesia vigilias, aut in crastino humationis prout tempus patietur, a quibus Domini Canonici marcam unam et viccarii aliam habebunt.

Vigilia anticipantur regulariter, quoties cadunt in diem no[n] vacantem.

A singulis vigiliis Archiepiscoporum trium marcarum, etsi excesserint taxam 10. marcar[um] vicariis gr[ossum] dantur a vigiliis vero Praelatorum et Canonicor[um] gr[ossos] 12 sol[v]untur. 